\title{
Hypomelanosis of Ito: a manifestation of mosaicism or chimerism
}

\author{
DIAN DONNAI, A P READ, CAROLE McKEOWN, AND \\ TONY ANDREWS \\ From the Regional Genetics Service, St Mary's Hospital, Manchester M13 0JH.
}

SUMMARY We describe three patients with the cutaneous manifestations of hypomelanosis of Ito. Two, with unusual abnormalities of their toes, had a mixture of diploid and triploid cells in cultured skin fibroblasts. The published clinical descriptions of hypomelanosis of Ito and diploidtriploid mosaicism are reviewed. Chromosome heteromorphisms, HLA types, and DNA fingerprints were studied in an attempt to elucidate the origin of the disease in our patients. We conclude that hypomelanosis of Ito is a manifestation of a heterogeneous group of disorders, the common factor being the presence of two genetically different cell lines. It can result from chromosomal mosaicism or chimerism, from a postzygotic mutation, or from $\mathrm{X}$ inactivation. The risk of recurrence is negligible if the proband is a male; if the proband is female the risk is also low but an $\mathrm{X}$ linked mutation must be considered.

Incontinentia pigmenti achromians, later renamed hypomelanosis of Ito ( $\mathrm{HI})$, was first described by Ito in $1952 .^{1}$ His patient was a 22 year old Japanese woman with hypopigmented lesions in a zigzag pattern around her trunk and in a linear pattern down her arms. No other physical abnormality was reported apart from asymmetry of breast size.

A recent review ${ }^{2}$ identified over 70 published reports of HI. The consistent feature is the cutaneous manifestation, which consists of hypopigmentation without preceding vesicular or verrucous stages. The hypopigmented skin is distributed over the body in a pattern which conforms to the lines of Blaschko, ${ }^{3}$ namely zigzag over the spine, circumferential around the trunk stopping at the midline anteriorly, and linear down the arms and legs. Histologically, the only consistently reported feature is a reduction in the number of melanin granules in the basal layer of the epidermis.

A total of $74 \%$ of the reviewed patients ${ }^{2}$ had one or more abnormalities of the central nervous system, eyes, hair, teeth, or musculoskeletal system. There was no consistent clinical pattern, suggesting that $\mathrm{HI}$ may be a heterogeneous disorder. Most cases are sporadic but there are three reports of familial $\mathrm{HI},{ }^{4-6}$ leading some authors to suggest that $\mathrm{HI}$ is an autosomal dominant condition with variable expression. The aetiology is not known and hence genetic

Received for publication 29 January 1988.

Revised version accepted for publication 30 March 1988. counselling is difficult for the families of affected subjects.

The fact that the skin markings follow Blaschko's lines led us to the hypothesis that all cases of $\mathrm{HI}$ are mosaics or chimeras. Interest in these lines, first described by Blaschko in 1901, was revived by Jackson in $1976 .{ }^{3}$ More recently, Happle ${ }^{7}$ has shown how females heterozygous for several $X$ linked conditions have skin variegations following Blaschko's lines. In one elegant demonstration, coloured starch powder was dusted over the back of a carrier of $\mathrm{X}$ linked hypohidrotic ectodermal dysplasia. The powder stuck only to the skin with sweat glands, showing the same swirling patterns as seen in incontinentia pigmenti and HI. The variegation seen in these heterozygous women is the result of Lyonisation and presumably represents clonal boundaries.

A similar variegated pattern following Blaschko's lines could result from any other event which produced, at the normal time of Lyonisation, a mixed population of cells giving different skin phenotypes. Experiments with mouse chimeras strongly support this view. The variegated coat patterns seen in females heterozygous for $\mathrm{X}$ linked genes such as tabby, which are the result of Lyonisation, can be reproduced in experimental chimeras made by combining cells from two homozygous female embryos. ${ }^{8}$ Since we started this work, Happle ${ }^{910}$ has suggested that several sporadic multisystem birth defects with skin manifestations 


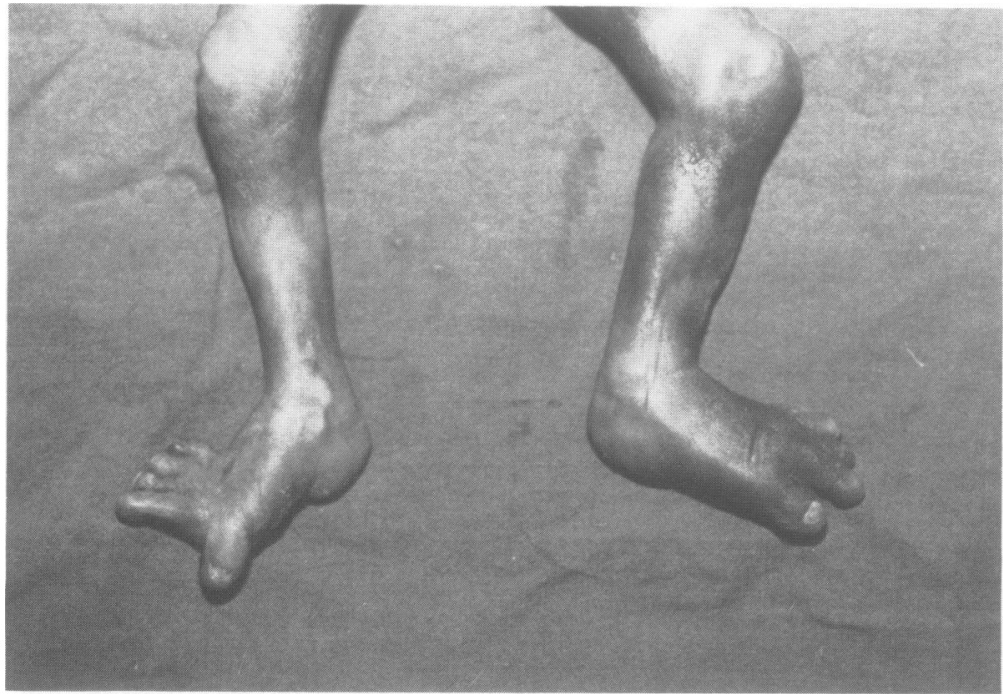

FIG 1 Feet of a triploid $(69, X X X)$ 18 week fetus. Note abnormal position of toes with second toe larger than big toe, and expanded ends of toes. following Blaschko's lines may be the result of lethal mutations surviving in mosaic form.

We have seen three patients with $\mathrm{HI}$ in our genetic clinic. Two of them had abnormal feet resembling those we have seen in triploid abortuses (fig 1). This observation prompted the chromosome and genetic marker studies reported here.

\section{Case reports}

\section{CASE 1}

Case 1 is the second daughter of healthy, nonconsanguineous, Caucasian parents. The mother was 27 and the father 39 years old at the time of her birth. The older girl is developmentally normal and there is no family history of retardation or skin depigmentation. Pregnancy and delivery were normal and her birth weight at term was $2670 \mathrm{~g}$. Hypotonia, an unusual facial appearance, and hand and foot abnormalities were noted. Delayed development was apparent by one year and her first convulsion occurred at two years when 'abnormal discolouration' of the skin over her lower trunk was first noted. Absence spells became more frequent by six years and responded to sodium valproate therapy. EEG showed irregular spike wave complexes mainly in the frontal area.

She was examined in the genetic clinic aged seven years six months: weight was $25.5 \mathrm{~kg}$ (50th centile) and height $123.5 \mathrm{~cm}$ (50th centile). She had facial asymmetry, the left side being larger than the right, scoliosis, and asymmetry of the trunk with the right side larger than the left. Her hands were long and narrow with flat ulnar borders; there was cutaneous syndactyly up to the proximal interphalangeal joints of digits 2 to 5 and the ends of her fingers were expanded. Her feet were long angd narrow with broad halluces and wide gaps betweep $\propto$ the halluces and the long second toes (fig 2). whorled hypopigmented pattern was noted over he्म back and round her trunk, stopping in the midline anteriorly. There was faint linear depigmentation down the outer aspects of her thighs and upper arms. A diagnosis of $\mathrm{HI}$ was made.

At 12 years of age her weight was $43 \mathrm{~kg}$ (50th to

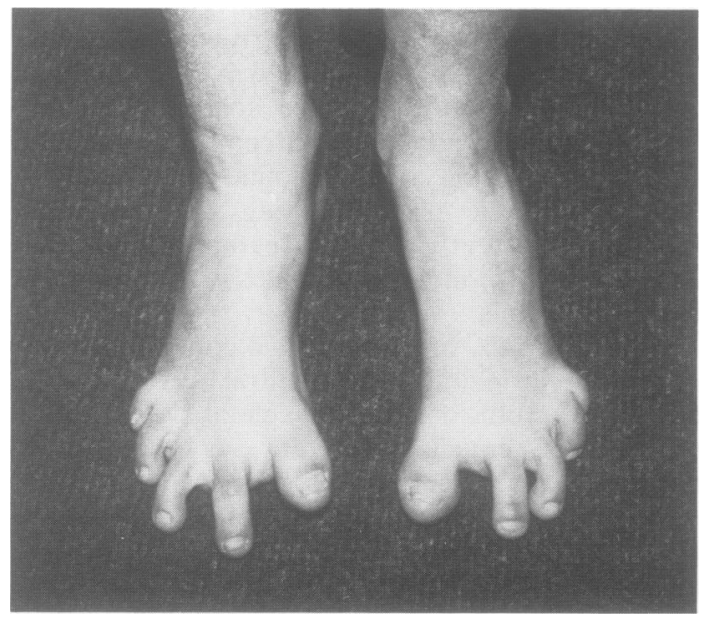

FIG 2 Feet of case 1 atseven years six months. Note abnormal position of toe and narrow feet. Note also that second and third toes are longer than big toe. 
75th centile), height $153 \mathrm{~cm}$ (75th centile), and OFC $52 \mathrm{~cm}$ (10th to 25 th centile). The facial asymmetry was more marked (fig 3 ). There was truncal obesity and asymmetry. The hypopigmented skin pattern

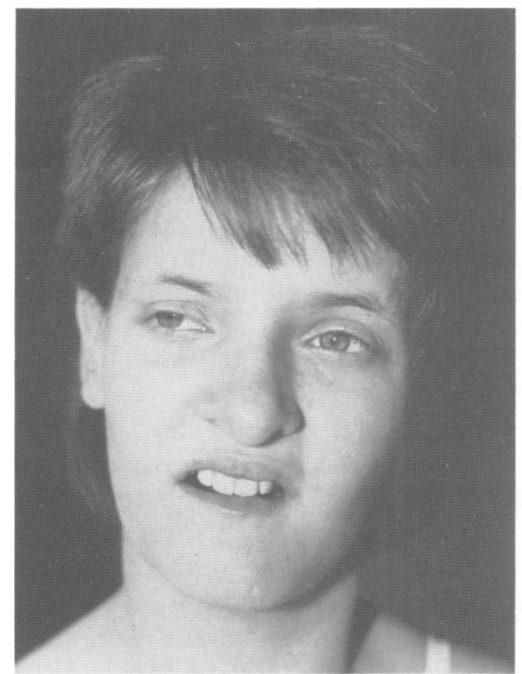

FIG 3 Case 1 at 12 years. Note facial asymmetry.

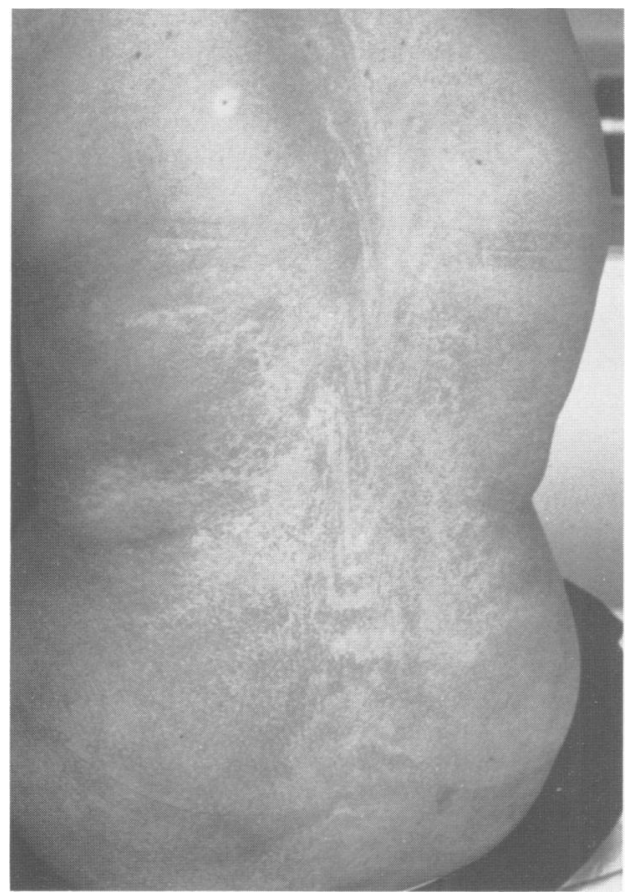

FIG 4 Back of case 1 at 12 years. Note zigzag pattern of depigmentation over spine and circumferential depigmentation around flanks. was marked over her back (fig 4), round the trunk, and down her thighs. There was good breast development, pubic and axillary hair were present, and menses are reported to have begun at the age of 10 years four months. The only abnormality on ophthalmological examination was heterochromia of the irides. She attends a school for mentally retarded children, her comprehension of simple commands is good, and she responds in short sentences.

\section{CASE 2}

Case 2 was the second daughter of a healthy, nonconsanguineous, Caucasian father aged 45 and mother aged 35 years. The older daughter, and two sons and two daughters from the father's first marriage are healthy and there is no family history of retardation or skin disorders. The pregnancy was complicated by vomiting and weight loss, and delivery at 35 weeks' gestation was by emergency caesarean section for placenta praevia. The baby weighed $2200 \mathrm{~g}$ (10th centile), length $48 \mathrm{~cm}$ (90th centile), and OFC $31 \mathrm{~cm}$ (10th centile). She was asphyxiated at birth and required endotracheal ventilation for eight minutes; prolonged apnoea at six hours necessitated reintubation and ventilation, and later several seizures were observed. When examined at five weeks (fig 5) her nose was

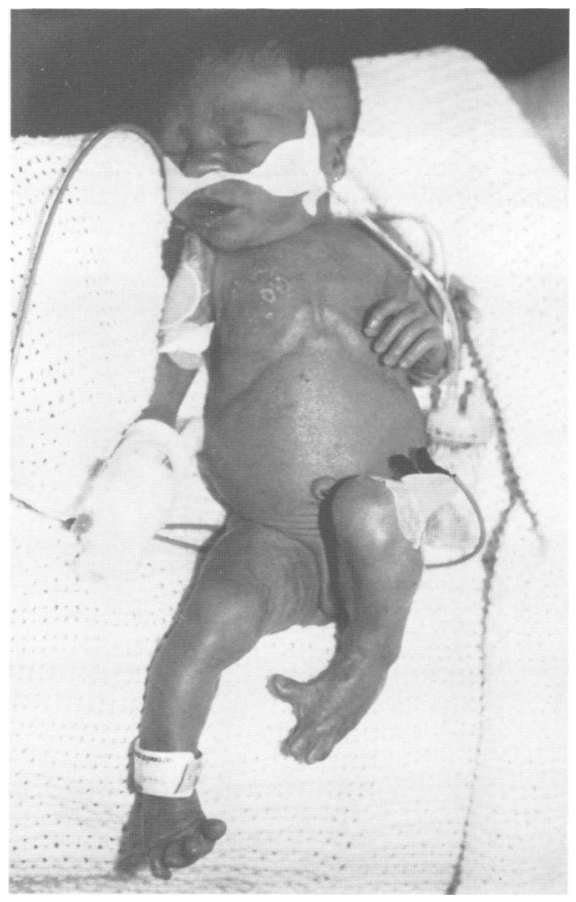

FIG 5 Case 2 at five weeks. Note abnormal position of toes and long fingers. 
prominent, her ears simple, and her tongue large. Her fingers were long and there was a wide gap between her first and second toes with medial deviation of the halluces. No unusual skin markings were observed.

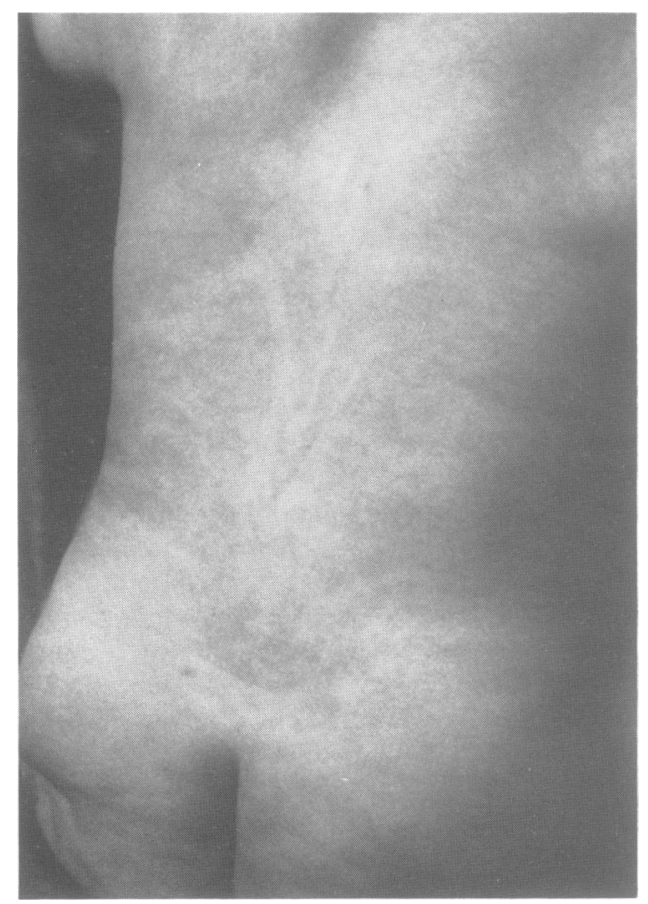

FIG 6 Back of case 2 at 111/2 months. Note zigzag depigmentation over spine.
At follow up at five months, her development was consistent with her chronological age and the previous physical findings were confirmed; in addition $\mathrm{V}$ shaped depigmentation over her back and linear depigmentation on her legs was observed, and a diagnosis of $\mathrm{HI}$ was made. On admission for further investigations at the age of $11 \frac{1}{2}$ months there was truncal obesity and asymmetry and the skin depigmentation was more marked over her $\vec{\circ}$ back (fig 6) and legs (fig 7). Ophthalmological examination under anaesthetic showed abnormal, yellow, drusen-like deposits in the peripheral retina together with diffuse pigmentary disturbance. She was making normal developmental progress. Surgery is planned to straighten the hallux of her left foot.

CASE 3

Case 3 was the first child of a healthy, nonconsanguineous, Caucasian 22 year old mother and 25 year old father. There is no family history of mental retardation or skin disorder and a younger sister is physically and developmentally normal. An uneventful pregnancy resulted in a normal delivery at 38 weeks of a male infant weighing $3100 \mathrm{~g}$ ( $<50$ th centile) with an OFC of $35 \mathrm{~cm}$ (75th centile) Developmental delay was apparent in his first yeato At 17 months a whorled depigmented pattern was observed on his trunk (fig 8) with linear depigmentation down his limbs (fig 9). Macrocephaly and asymmetry of his trunk and limbs were also noted and a diagnosis of HI was made.

He was admitted for investigation at four years seven months when his weight was $17.2 \mathrm{~kg}$ (25th to 50 th centile), height $105 \mathrm{~cm}$ (50th centile), and OFC

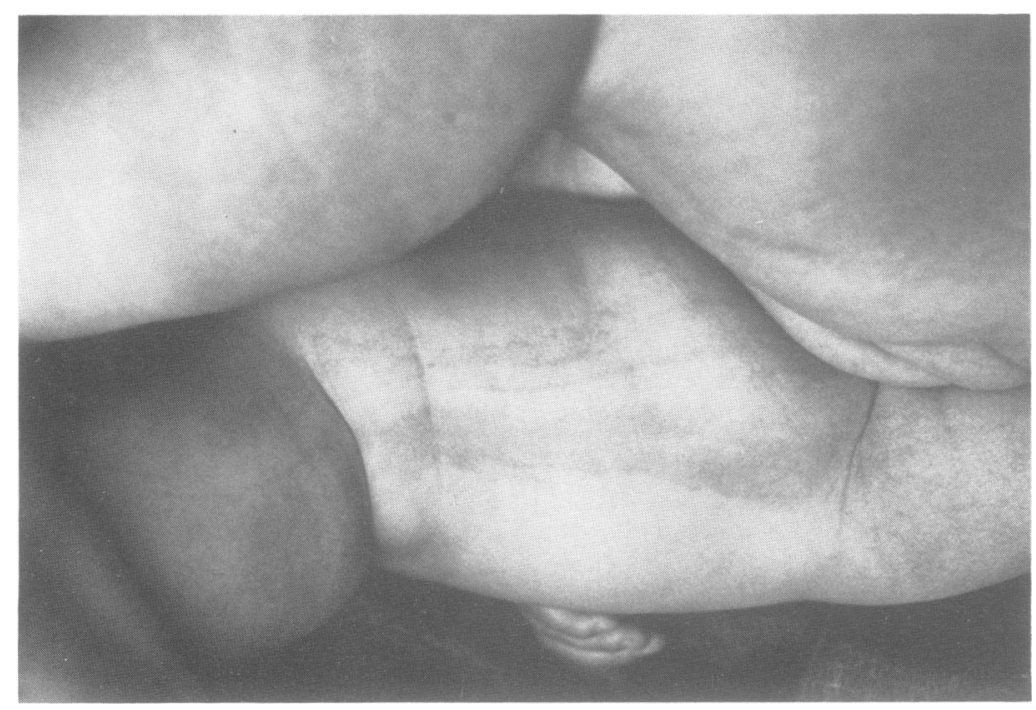

FIG 7 Back of thighs of case 2 at $111 / 2$ months. Notelinear depigmentation. 
$55 \cdot 5 \mathrm{~cm}$ ( $>97$ th centile). The asymmetry (fig 10) and depigmentation was more marked. Ophthalmological examination showed no abnormalities. He attends a school for moderately educationally subnormal children; his language development is severely delayed and seizures are difficult to control.

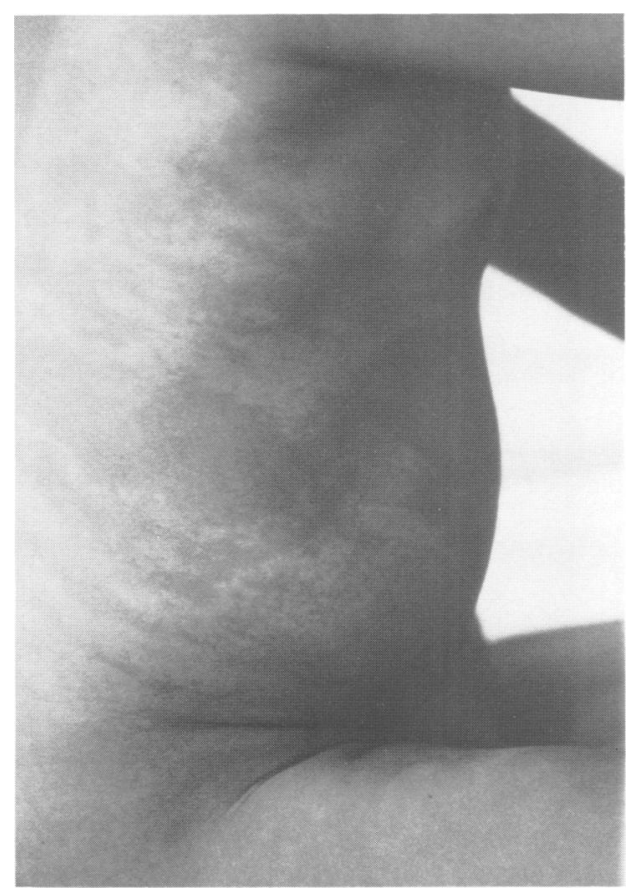

FIG 8 Right side of trunk of case 3 at 17 months. Note swirling depigmented areas.

\section{Methods}

Full thickness skin biopsy specimens were taken from each child from a hypopigmented and a normally pigmented area of the back of the trunk. Fibroblasts from these samples were cultured for cytogenetic and DNA analysis. Blood samples were taken from the children and their parents for lymphocyte culture, cytogenetic analysis, and DNA extraction, and from case 3 and his parents for HLA studies.

DNA was extracted from peripheral blood lymphocytes or cultured fibroblasts by standard methods. " Samples were digested with the restriction enzyme HinfI (BRL) under the recommended conditions, and electrophoresed in a $40 \times 10 \mathrm{~cm}$ $0 \cdot 8 \%$ agarose gel for 40 hours, until a $2 \mathrm{~kb}$ size marker had run $35 \mathrm{~cm}$. After transfer to Hybond-N membrane (Amersham), filters were hybridised with radiolabelled probe 15.1 .11 or 6.3 , two versions of the minisatellite probe ${ }^{12}$ kindly donated by Dr Alec Jeffreys. The probes were cloned into M13, double stranded linear copies excised using HaeII (which leaves part of the M13 polylinker on each end of the excised fragment), and labelled by polymerisation using a mixture of M13 positive and negative strand primers.

HLA-A and B types were scored by a standard lymphocytotoxic technique using antisera characterised on a cell panel which had been typed with VIIIth and IXth International Histocompatibility Workshop antisera.

\section{Results}

CYTOGENETIC STUDIES

All blood lymphocyte cultures showed normal

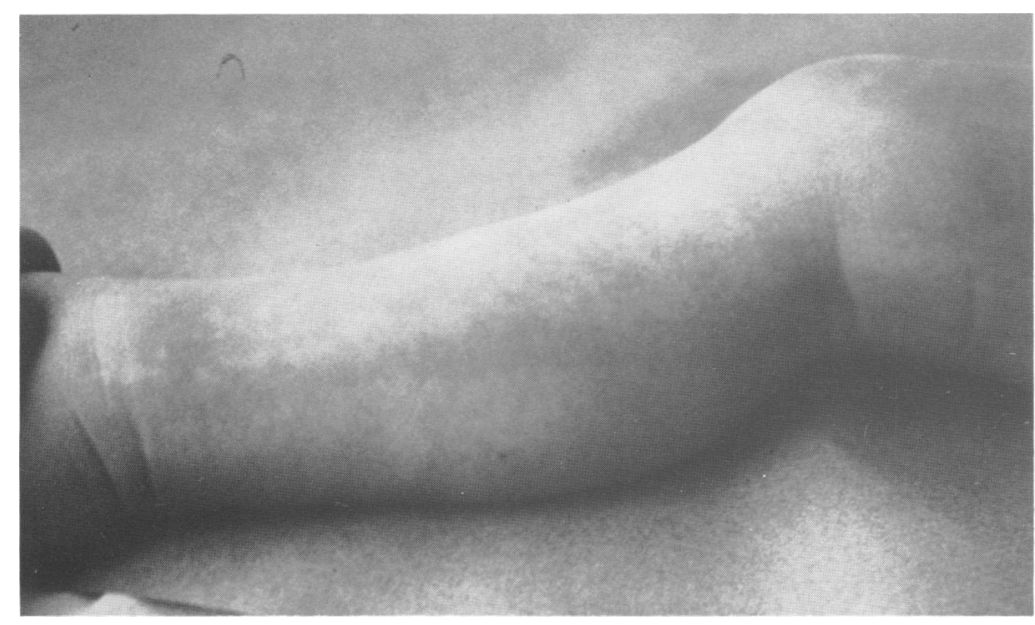

FIG 9 Rightlegofcase 3 at 17 months. Notelinear depigmentation. 
diploid cells, 46,XX for cases 1 and 2 and 46,XY for case 3. A total of 100 cells was counted from each patient. Triploid cells were seen in cultured fibroblasts from skin biopsy specimens from case 1 (84\% 69, XXX, 100 cells analysed) and case 2 (41\% 69, XXX, 100 cells analysed), but not case 3 (100 cells $46, X Y)$. The triploid cells were seen in approximately equal numbers in fibroblasts cultured from hypopigmented and normal skin. The mother of case 2 had a 1qh+ marker chromosome which was also seen in the diploid and triploid cells of her daughter. Triploid cells had only one copy of this marker.

\section{HISTOLOGY}

Light microscopic examination of the skin biopsy samples from all three patients showed similar features. In the hypopigmented skin there was little or no pigment in the basal layer of the epidermis. In the apparently normal skin, pigment was seen although in a patchy distribution through the basal layer. Apart from these changes, the epidermis and dermis and associated structures were normal.

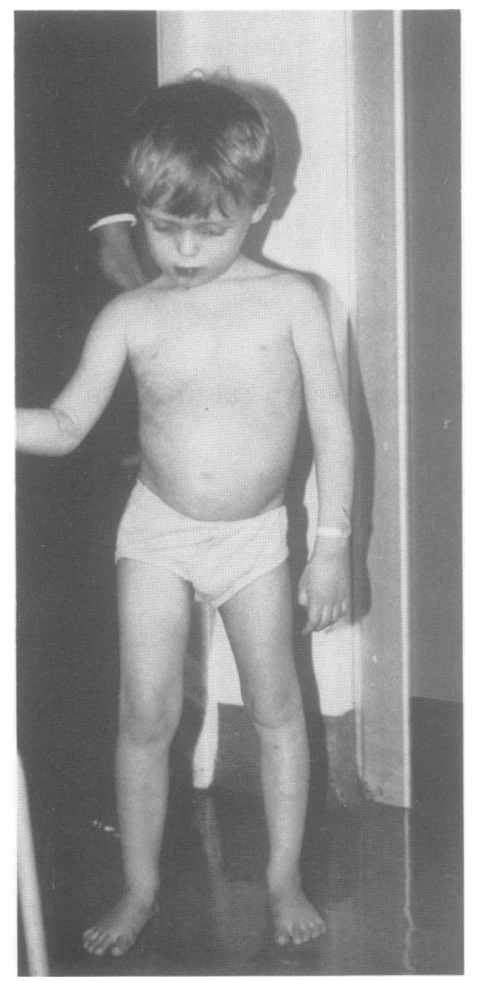

FIG 10 Case 3 at four years seven months. Note right leg is longer and thicker than left and left side of chest is larger than right.
DNA MARKER STUDIES (FIG 11)

Case 1

Combining results with the two minisatellite probes 15.1.11.4 and 6.3, blood DNA showed 12 of the 26 paternal bands and 14 of the 25 maternal bands.

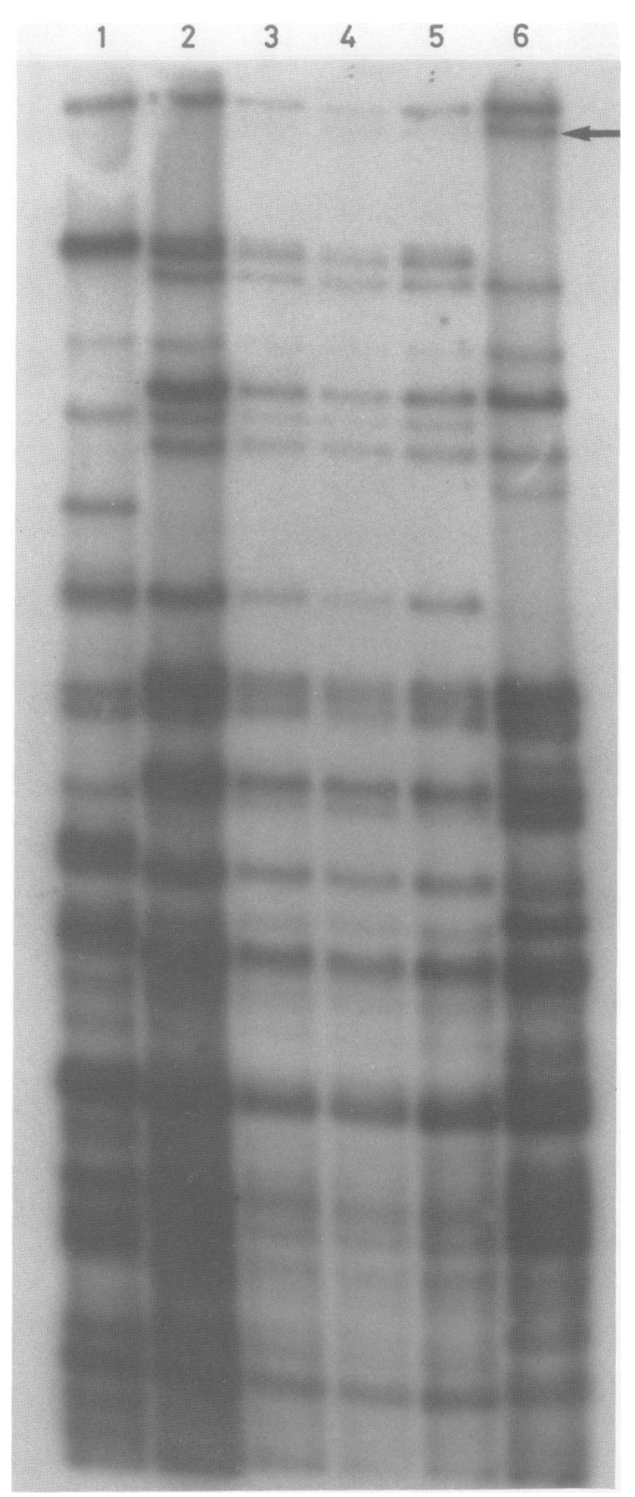

FIG 11 DNA fingerprint of blood (diploid) and fibroblast (mixed diploid-triploid) DNA from case 1 and blood from her parents, using the minisatellite probe 15.1.11.4. Track 1 father, track 2 case 1 blood, tracks 3 to 5 case 1 fibroblasts, track6mother. Arrow marks a maternal band present in fibroblasts but absent in blood. 
Fibroblasts showed all bands seen in the blood and in addition five extra bands, four of which were maternal in origin; the fifth could have been maternal or paternal as each parent had a band at that position. All the extra bands were faint. One can be seen in fig 11; the others, though sharp, are too weak to photograph well. Several maternal bands appeared to be absent from the fibroblast DNA, but allowing for the weakness of the extra bands which were present, it was not possible to be completely certain that any maternal band was absent from the fibroblasts.

\section{Case 2}

Blood DNA showed nine of the 21 paternal bands and 11 of the 23 maternal bands. Fibroblasts showed exactly the same bands, with no extra ones. On a heavily overexposed autoradiograph, seven maternal and two paternal bands were unambiguously absent from the fibroblasts.

\section{HLA STUDIES}

Blood from case 3 and his parents was typed for HLA-A, B, and C antigens. Results were:

Father: A2, B62, Cw3/All, B27, Cw2.

Mother: A26, B44, Cw7/A29, B-, Cw-.

Case 3: A2, B62, Cw3/A26, B44, Cw7.

\section{Discussion}

CLINICAL SIMILARITY OF DIPLOID-TRIPLOID MIXOPLOIDY AND HI

We have traced reports of 15 subjects with mixed diploid and triploid cells. ${ }^{13-27}$ Four died in the perinatal period; the others were between nine months and 21 years old when last reported. Of these 11 survivors, five were male, four female, and two had ambiguous genitalia. All 11 showed developmental retardation and skeletal abnormalities including syndactyly and joint contractures; other features included asymmetry in seven and fits or EEG abnormalities in seven. Skin abnormalities included large, serrated, pigmented spots on the right trunk, ${ }^{15}$ "irregular skin pigmentation on the right leg at birth; at eight years pigmentary change of the skin more pronounced", 25 and "abnormal pigmentation of both legs consistent with incontinentia pigmenti", 27

Many reported cases of $\mathrm{HI}$ have had mental retardation, asymmetry, skeletal abnormalities including scoliosis and joint contractures, and fits. ${ }^{2} 28$ We have drawn attention to the similarity between the feet of two of our three HI cases and those of full triploid abortuses. Clearly the clinical features of HI and of diploid-triploid mixoploidy show consider- able overlap. It is likely that a diagnosis of $\mathrm{HI}$ is more readily made in dark skinned races where the hypopigmentation is striking. In the review of $\mathrm{HI}$ by Takematsu et $a l,{ }^{2}$ of the 56 cases where we could identify the racial origin, 51 were from dark skinned races, whereas all 15 reported cases of diploidtriploid mixoploidy have been from white skinned races.

\section{THE MECHANISMS PRODUCING}

DIPLOID-TRIPLOID MIXOPLOIDY

Triploid conceptuses are common. Niebuhr ${ }^{29}$ and Jacobs et $a l^{30}$ have reviewed the findings and mechanisms. They can arise from dispermy, fertilisation of a normal ovum by a diploid sperm, fertilisation of a diploid ovum by a normal sperm, or fusion of the zygote with the second polar body. Diploid-triploid mixoploids are less well understood. The most plausible mechanisms are chimerism of full diploid and full triploid conceptuses or incorporation of the second polar body into one of the later cleavage nuclei of a diploid zygote. More speculatively perhaps one cleavage nucleus of a triploid zygote could lose a haploid complement in a tripolar mitosis. 29

Each of these mechanisms can lead to different genetic relationships between the diploid and triploid tissues. Genetic marker studies may identify the mechanism responsible.

(1) In a chimera, the diploid and triploid tissues will contain different genetic markers of both maternal and paternal origin.

(2) Fusion with the second polar body will produce genetically identical diploid and triploid tissues, except that the triploid tissue will show both alleles of any maternal marker where the mother was heterozygous and recombination has led to second division segregation. These extra alleles would be seen with markers mapping in the distal parts of chromosomes, but not with markers near the centromeres.

(3) Loss of one haploid set from a triploid could lead to widely varying findings, depending on the origin of the triploid and on which haploid set was lost. Loss of one paternal set from a dispermic triploid is perhaps the most likely event, producing diploid tissue lacking some paternal markers present in the triploid tissue.

In summary, if the tissues show many differences in markers from both parents, the cause is chimerism; if the differences are in the paternal complement only, the mechanism involved double fertilisation or possibly a diploid sperm; and if the differences are in the maternal set only, a polar body was involved.

Studies of markers have been reported in several of the published diploid-triploid cases. In two, ${ }^{14} 15$ 
the triploid tissue contained extra maternal markers. In two, ${ }^{22}{ }^{24}$ there was an extra paternal complement; one ${ }^{16}$ with chromosome constitution 48, $\mathrm{XXYY} / 71, \mathrm{XXXYY}$ was ascribed to fertilisation by an abnormal sperm followed by incorporation of the second polar body, and one ${ }^{17}$ with $46, X X / 69, X X Y$ chromosomes was probably a chimera. The minisatellite probe of Jeffreys ${ }^{12}$ greatly expands the power of such marker studies, provided that the diploid and triploid tissues can be separated.

In our case 1 , the presence of extra maternal markers in the mixed diploid-triploid fibroblasts compared to the pure diploid blood clearly points to a failure of maternal meiosis. The extra bands were faint, and in retrospect we suspect that the proportion of triploid cells in the samples grown for DNA extraction was considerably lower than in the shorter term cultures used for cytogenetic analysis. Because the extra bands were faint, we cannot be certain that maternal bands which were not seen really were absent from triploid cells, though this seems likely. Thus, we believe this patient arose by incorporation of the second polar body into a cleavage nucleus, but we cannot rule out reincorporation of the first polar body or failure of the first division of maternal meiosis followed by loss of one maternal haploid set.

In case 2, the triploid cells carried only one copy of a maternal $1 \mathrm{qh}+$ marker chromosome. This is a centromeric marker which therefore could not segregate at the second division of meiosis. This rules out the mechanism we favour for case 1 , incorporation of the second polar body. With the minisatellite probes, we could show no differences between the diploid and triploid tissues. Unfortunately, the most likely explanation for this is that there were very few triploid cells in the cultures used for DNA extraction. The cytogenetic cultures from this patient showed only half as many triploid cells as case 1 . This leaves the mechanism of origin uncertain. Perhaps case 2 started as a triploid by fertilisation by two sperm or by a diploid sperm where the second division had failed, and that later one paternal complement was lost in one cell line.

In future investigations of diploid-triploid mixoploids it would be advisable to use DNA from separated pure triploid cells for the marker studies, and to put more emphasis on chromosome heteromorphisms. In particular, fluorescent heteromorphisms ${ }^{30}$ would probably allow the origin of the triploid cell line to be established unambiguously from studies of the parents' blood and the mixed diploid-triploid fibroblasts.

OTHER CAUSES OF HI

Non-triploid mosaics and chimeras have been described with clinical features which overlap HI. A man with mosaic trisomy 18 had mental retardation, joint contractures, facial and body asymmetry, and linear hyperpigmented areas with precise limitation at the midline. ${ }^{31}$ The distribution of the skin findings was consistent with Blaschko's lines. Mosaics for $12 p$ tetrasomy, where the abnormal cell line is found in the skin, show a characteristic appearance, but some children have been described as having linear skin pigmentary changes. ${ }^{32}$ Cases of diploid-tetraploid mosaicism ${ }^{33} 34$ show severe mental and physical retardation, peculiar facies, and flexion deformities of the joints. Pigment abnormalities of the skin have been described in chimeras identified through blood group testing. ${ }^{35} \mathrm{XX} / \mathrm{XY}$ chimeras are often ascertained through intersexuality, but $\mathrm{XX} / \mathrm{XX}$ or $\mathrm{XY} / \mathrm{XY}$ chimeras may only be detected by blood grouping or skin abnormalities.

Since our preliminary report of these three patients ${ }^{36}$ there have been several reports of HI or skin pigmentation in the lines of Blaschko with chromosomal mosaicism, many with the abnormal cell line detectable only in skin fibroblasts. ${ }^{37-39}$

Our case 3 had only 46,XY cells in his blood and skin. We sought evidence that he might be an $\mathrm{XY} / \mathrm{XY}$ chimera in four ways.

(1) We looked for chromosomal heteromorphisms in the parents which could be used to see whetheo both homologues of one parental pair could be found in different cells of the boy. We were unable to find any useful heteromorphisms in either parent (but we did not try fluorescent heteromorphisms ${ }^{30}$ ).

(2) We looked for differences in the band pattern with the minisatellite probe between the boy's blood and skin. We found none, but this could simply mean that both cell lines were present in all samples.

(3) We tested $X$ linked DNA polymorphisms in the boy's blood for heterozygosity, which would show the presence of both $\mathrm{X}$ chromosomes from his mother. We found none with six polymorphisms.

(4) We checked the HLA-A and B types of the blood, but found only two antigens at each locus.

The findings do not rule out chimerism, but it is more likely that case 3 is a genetic mosaic for a postzygotic mutation.

THE INHERITANCE OF HI

HI is normally sporadic, but three reports claim familial occurrence.

Groshans et $a l^{4}$ report a mother and three daughters. The only abnormality reported in the mother was an irregular depigmented lesion on one buttock. The three daughters aged between 18 months and four and a half years were severely retarded and had depigmented lesions on their trunks, present from birth and becoming less obvious 
after the age of three years. Skin biopsy of these girls showed decreased melanin granules but also atrophy of the sweat glands and aplasia of the hair roots. The family history is consistent with an $\mathrm{X}$ linked disorder with lethality in affected males, but the histology is not characteristic of HI. Similar histological findings are seen in $\mathrm{X}$ linked chrondrodysplasia punctata. ${ }^{40}$

Rubin $^{5}$ described and illustrated a female case of undoubted $\mathrm{HI}$; her father was reported to have had a similar skin problem which faded by the age of 20 , but no further clinical details or illustrations are given. The father's brother was reported to have had a similar problem, but again he was not available for examination. The proband's two older brothers were reported as having macular hypopigmented areas on the chest and the dorsum of their feet. No illustrations were published of these boys, and the description would be consistent with vitiligo.

The third report of familial HI was a four year old girl reported by Jelinek et al ${ }^{6}$ whose dead paternal great aunt was said to have had similar skin findings. No further clinical details were given.

We do not believe these three reports are sufficient to prove the existence of familial HI.

\section{CLINICAL IMPLICATIONS}

We have shown that $\mathrm{HI}$ is heterogeneous. Skin biopsy is indicated for histology and fibroblast culture. Evidence for chimerism might be sought by blood grouping or HLA typing. For all male patients, and for females where chimerism or mosaicism can be shown, the recurrence risk is low. If no chimerism or mosaicism can be found, the possibility cannot be ruled out that a female patient has an $\mathrm{X}$ linked condition with an appreciable recurrence risk. There is no good evidence, anecdotal or theoretical, for the view that HI is autosomal dominant. Some cases are probably $\mathrm{X}$ linked. The family reported by Groshans $e t a l^{4}$ would be an example if the diagnosis of $\mathrm{HI}$ is accepted, and in the review by Takematsu et $a l^{2}$ there was a $2 \cdot 5: 1$ excess of females over males with HI. Nevertheless, though the recurrence risk of HI is low, the risk of abnormalities among children of HI patients may not be so low, if a mutant cell line is present in the germ line.

We thank Dr F Bamford for referring cases 1 and 3 , and $\mathrm{Mr} \mathrm{A}$ Bianchi for referring case $2 ; \mathrm{Dr} \mathrm{R} \mathrm{H}$ Macdonald kindly reported the skin histology; and Dr P A Dyer reported HLA types. We are grateful to Roger Mountford for expert assistance with DNA work and Dr Alec Jeffreys for the gift of minisatellite probes. We would also like to thank our three patients and their parents for their cooperation in this study.

\section{References}

1 Ito M. Studies on melanin. IX. Incontinentia pigmenti achromians - a singular case of nevus depigmentosus systematicus bilateralis. Tohoku J Exp Med 1952;55(suppl):57-9.

2 Takematsu H, Sato S, Igarashi M, Seiji M. Incontinentia pigmenti achromians (Ito). Arch Dermatol 1983;119:391-5.

3 Jackson R. The lines of Blaschko: a review and reconsideration. Br J Dermatol 1976;95:349-60.

4 Groshans EM, Stoebner P, Bergoend H, Stoll C. Incontinentia pigmenti achromians (Ito) -étude clinique et histopathologique. Dermatologica 1971;142:65-78.

${ }^{5}$ Rubin MB. Incontinentia pigmenti achromians-multiple cases within a family. Arch Dermatol 1972;105:424-5.

6 Jelinek JE, Bart RS, Schiff GM. Hypomelanosis of Ito (incontinentia pigmenti achromians)-report of three cases and review of the literature. Arch Dermatol 1973;107:596-601.

${ }^{7}$ Happle R. Lyonisation and the lines of Blaschko. Hum Genet 1985;70:200-6.

${ }^{8}$ McLaren A, Gauld IK, Bowman P. A comparison between mice chimaeric and heterozygous for the X-linked gene tabby. Nature 1973;241:180-3.

${ }^{9}$ Happle R. The McCune-Albright syndrome: a lethal gene surviving by mosaicism. Clin Genet 1986;29:321-4.

10 Happle R. Cutaneous manifestations of lethal genes. Hum Genet 1986;72:280.

"Maniatis T, Fritsch EF, Sambrook J. Molecular cloning: a laboratory manual. New York: Cold Spring Harbor Laboratory, 1982.

12 Jeffreys AJ, Wilson V, Thein SL. Hypervariable minisatellite regions in human DNA. Nature 1985;314:67-73.

13 Böök JA, Santesson B. Malformation syndrome in man associated with triploidy (69 chromosomes). Lancet 1960;i:858-9.

14 Ellis JR, Marshall R, Normand ICS, Penrose LS. A girl with triploid cells. Nature 1963;198:411.

15 Ferrier P, Stalder G, Bamatter F, Ferrier S, Buehler E, Klein D. Congenital asymmetry associated with diploid-triploid mosaicism and large satellites. Lancet 1964;i:80-2.

${ }^{16}$ Schmid W, Vischer D. A malformed boy with double aneuploidy and diploid-triploid mosaicism 48,XXYY/71,XXXYY. Cytogenetics 1967;6:145-55.

17 Lejeune J, Salmon CH, Berger R, Rethoré MO, Rossier A, Job JC. Chimere 46,XX/69, XXY. Ann Genet (Paris) 1967;10: 188-92.

18 Sacrez R, Clavert J, Willard D, et al. La triploidie chez l'enfant. Pediatrie 1967;22:267-75.

${ }^{19}$ van den Berghe H, Verresen H. Triploid-diploid mosaicism in the lymphocytes of a liveborn child with multiple malformations. Humangenetik 1970;11:18-21.

${ }^{20}$ Jenkins ME, Eisen J, Sequin F. Congenital asymmetry and diploid-triploid mosaicism. Am J Dis Child 1971;122:80-4.

${ }^{21}$ David M, Chambon A, Laurent C, et al. La triploidie chez l'enfant. I. Étude du phenotype. Pediatrie 1975;30:281-98.

22 Dewald G, Alvarez MN, Cloutier MD, Kelalis PP, Gordon H. A diploid-triploid human mosaic with cytogenetic evidence of double fertilisation. Clin Genet 1975;8:149-60.

${ }^{23}$ Fryns JP, Vinken L, Geutjens J, Marien J, Deroover J, van den Bergh $\mathbf{H}$. Triploid-diploid mosaicism in a deeply mentally retarded child. Ann Genet (Paris) 1980:23:232-4.

${ }^{24}$ Graham JM, Hoehn H, Lin MS, Smith DW. Diploid-triploid mixoploidy: clinical and cytogenetic aspects. Pediatrics 1981;68: 23-8.

${ }^{25}$ Tharapel AT, Wilroy RS, Martens PR, Holbert JM, Summitt $\mathrm{RH}$. Diploid-triploid mosaicism: delineation of the syndrome. Ann Genet (Paris) 1983;26:229-33.

${ }^{26}$ Pettenati MJ, Mirkin LD, Goldstein DJ. Diploid-triploid mosaicism: report of necropsy findings. Am J Med Genet 1986;24:23-8.

${ }^{27}$ Fulton AB, Howard RO, Albert DM, Hsia YE, Packman S. Ocular findings in triploidy. Am J Ophthalmol 1977;84:859-67. 
${ }^{28}$ Schwartz MF, Esterly NB, Freyzin DF, Pergament E, Rozenfeld IH. Hypomelanosis of Ito (incontinentia pigmenti achromians): a neurocutaneous syndrome. J Pediatr 1977;90:236-40.

${ }^{29}$ Niebuhr E. Triploidy in man. Hum Genet 1974;21:103-25.

30) Jacobs PA, Angell RR, Buchanan IM, Hassold TJ, Matsuyama AM, Manuel B. The origin of human triploids. Ann Hum Genet 1987;42:49-57.

31 Chemke J, Rappaport S, Etrog R. Aberrant melanoblast migration associated with trisomy 18 mosaicism. J Med Genet 1983;20:135-7.

32 Carey JC, Morgan C, Palumbos JC, Webb MJ, Reynolds JF, Opitz JM. The Pallister mosaic, Killian and 12p marker syndromes: evolution of a single entity. Proc Greenwood Genetic Center 1986;5:131.

33 Quiroz E, Orozco A, Salamanca F. Diploid-tetraploid mosaicism in a malformed boy. Clin Genet 1985;27:183-6.

34 Wittwer BB, Wittwer HB. Information about diploid-tetraploid mosaicism in a six-year-old male. Clin Genet 1985;28:567-8.

35 Findlay GH, Moores PP. Pigment anomalies of the skin in the human chimaera: their relation to systematised naevi. $\mathrm{Br}$ Dermatol 1980;103:489-98.

36 Donnai D, McKeown C, Andrews T, Read AP. Diploid/triploid mixoploidy and hypomelanosis of Ito. Lancet 1986;i:1443-4.

${ }^{37}$ Rott HD, Ulmer R, Haneke E. Hypomelanosis of Ito and chromosomal mosaicism in fibroblasts. Lancet 1986;ii:343.

${ }^{38}$ Thomas IT, Frias JL. Hypomelanosis of Ito and chromosomal mosaicism in fibroblasts. Lancet 1986;ii:343.

39 Turleau C, Taillard F, de Bazigram MD, Delepine N, Debois JC, de Grouchy J. Hypomelanosis of Ito (incontinentia pigmenti achromians) and mosaicism for a microdeletion of $15 \mathrm{q} 1$. Hum Genet 1986;74:185-7.

40 Wettke-Schafer R, Kantner G. X-linked dominant inherited diseases with lethality in hemizygous males. Hum Genet 1983;64:1-23.

Correspondence and requests for reprints to Dr D Donnai, Department of Medical Genetics, St Mary's Hospital, Hathersage Road, Manchester M13 0JH. 